EJSM Vol. 17, 1/2016, ISSN: 2450-8535 | www.wnus.edlu.pl/pl/ejsm | D0l: 10.18276/ejsm.2016.17/1-07 | 51-56

\title{
ANALYSIS OF MULTIDIMENSIONAL INFORMATION STRUCTURES IN ECONOMIC SERVICE PROCESS - NONLINEAR APPROACH
}

\author{
ELŻBIETA SKĄPSKA
}

\begin{tabular}{|c|c|}
\hline & $\begin{array}{l}\text { Bialystok University of Technology, POLAND } \\
\text { e-mail: e.skapska@pb.edu.pl }\end{array}$ \\
\hline $\begin{array}{l}\text { RECEIVED } \\
\text { ACCEPTED }\end{array}$ & $\begin{array}{l}3 \text { January } 2016 \\
1 \text { March } 2016\end{array}$ \\
\hline $\begin{array}{l}\text { JEL } \\
\text { CLASSIFICATION }\end{array}$ & D02.F06 \\
\hline KEYWORDS & multidimensional services, information, rationalization of economic activity \\
\hline ABSTRACT & $\begin{array}{l}\text { Advancing automation of services lessens human's participation in providing services. Until now the research } \\
\text { done by economists has included the depiction of "the new economy", mainly in the field of production, where } \\
\text { information is connected to information technology and, at the same time, marginalizing the services. The aim } \\
\text { of the article is obtaining a model of a rational service provider that functions in multidimensional space of their } \\
\text { activity: classical (direct) and digital through identifying the stages of a service provision process. In order to } \\
\text { achieve the goal hypothetico-deductive and algorithmic methods were applied. The results of the analysis are } \\
\text { the contribution to further research. They are the first step towards drawing up comprehensive understanding of } \\
\text { the specificity of the process, in which one provides services. However the lack of exact repetition of economic } \\
\text { occurrences may constitute a limitation while identifying the abovementioned stages. No exact repetition con- } \\
\text { ditions arise from strong emotional influence under which a service provider is. Nevertheless, the evaluation } \\
\text { made in the article may be an incentive to activate the elements responsible for efficiency of a service organiza- } \\
\text { tion and the elements that eliminate factors destabilizing efficient operation of a service provider. }\end{array}$ \\
\hline
\end{tabular}

\section{Introduction}

This fact is undisputable: the essential feature of all economic processes is rational operation. Each and every attempt to create a model of rationality, which according to O. Lange (1904-1965) and T. Kotarbiński (1886-1981) is understood in the context of a subject's knowledge, their access to information and ability to process and use it, originally constitutes an attempt to improve the operation of a single enterprise. The action becomes rational, that is 
correct, when it is in accordance with the frugal principle, which has functioned in literature since the half of the 18th century. Thus administration is considered rational when the subject, that is to achieve the preferred goal, selects, based on their knowledge (information), the most effective means. The disregard for legitimacy of goals and morality of means challenges the sense of rationality and reason. Although economic activity is generally rational there is no the one rationality. It is gradable as the more rational projects, plans and activities appear.

In service-related selection a decision-maker seeks for regularities that enforce rationality. From their point of view the most important elements seem to be: ownership, institutions and institutional systems, economic calculation, experience-based knowledge and information (Skąpska, 2014).

One should consider a multidimensional family of transformations (Jakimowicz, Juzwiszyn, 2012) $f_{i}: R^{n} \rightarrow R^{m}$, where $i, n, m$ are elements of the $N_{+}$set as a regularity of that process. $f_{i}$ is the $i$-th function of economic decisions made by an entity. $R^{n}-n$-dimensional space of information technology originating from the production sector. $R^{m}$ - m-dimensional space of economic effects treated as sub-space of the global economic market.

Due to the increased importance of information - the subject of the herein study analysis - and the IT sector, the role of services, as well as the requirement threshold for the quality personnel providing services, increased too. It is worth noting that the features of services have changed during the development of civilization and this has resulted in creation of the need for alterations in a service entrepreneur's character. In the world defined as cyberspace, personality (Rogoziński, 2003) is, most of all, a certain organization of encoded information in human's memory. The changing "of less efficient techniques into the more efficient ones" takes place in the process of a market transformation that assumes the form of creating new products, services, skills or new markets (Leibenstein, 1995).

The article draws special attention to development of relationship between a person providing services and a service user - a client; in multidimensional spaces that are connected with traditional and modern movement of services, characterized by information, creating diverse conditions for a service provider's job. Thanks to the provision of work, a service relation, which is generally of social nature, gains economic importance and may be a subject to a microeconomic analysis. Information has features of economic information.

\section{Information as an economic category}

In order to exert an influence on shaping economic occurrences, economic information must meet certain requirements (Mytlewski, 2007): forms of presenting information material should be articulate and commensurate with the reading skills of the information receivers; information "produced" in a given system should be up-to-date and the costs of its processing should be optimally low; one should exclude possibility of doubling information while integrating individual subsystems of information; one must pursue eliminating all the obstacles and disruption causing distortion of information.

It is possible to identify economic information, moreover, due to its features (Rogoziński, 2000): it is clearly under the influence of information technology; the need for objectiveness concerns facts, features, parameters, quantitative data; content and essence of the message are of utmost importance; precise, efficient; it reaches firm receivers; and uses modern means of communicating. First successful attempts of defining the methods of transmission were made by C.E. Shannon. He produced many important mathematical formulas which constitute the basis of the modern theory of information. According to the basic model of transmission, information is passed from the source through a sender/transmitter, and then via a communication channel and through the receiver to a final receiver of information. It is transmitted in a more or less distorted form. The level of distortion depends on the 
quality of the applied senders/transmitters and receivers. The quality of the communication channel is equally vital. The theories of Shannon underlie the basis of contemporary expansion of computers and the Internet (Shannon, 1948).

Popularization of quick and cheap transmission, mainly ICT technology, contributes to changes of conditions for providing services. They go towards spatial freedom that is the lack of necessity for combining activity at one place at one time thus they create new types of services. Generating individual components of the service process may be located with no obstacles in different countries and different parts of the world. Currently because of the ICT sector and the access to modern service-product offers, economic reality is "filled with" visualization, which has indirectly imposed a new style of market behavior in both entrepreneurs and clients. The design used in service activity, i.e. designing the contents of a service product, is simultaneously shaped at the level of its internal complexity as well as at the general level of the designed product. They provide for each other. From the beginning, an untypical subject of the design process is co-created with a service receiver. The condition for applying the service design at an early stage and the development of this proficiency is moving this design to the level of the contact personnel (Rogoziński, 2014).

\section{Nature of service providing process}

Economists did not perceive services as a production component and their economic value for a long time. Underestimating services concerned not only their poor usefulness and trade ability, but also the lack of rationality (effectiveness, profitability, efficiency) while undertaking service endeavors. In the search for the truth among philosophers and economists, J.B. Say (1767-1832) was the first service economy creator who appreciated economic dimension of services and thereby discontinued viewing services as unproductive in business administration.

Interpretation of conditions for providing services and, first of all, asymmetricality of information is impossible to determine without establishing current service features. In subject literature there is a classical set of features which make up the nature of services and their distinctness in relation to tangible property. They are (Payne, 1993): Intangibility - mostly, they are not connected with the production of tangible goods; Diversity - they are not unitary or standard, but very diversified; Inseparability - they are provided by a service provider and, at the same time, consumed by a client; Impermanence - it is impossible to store them.

One may write down the following sequences (Rogoziński, 2010) in the process of rendering services: 1. Communicating - designing service. 2. Occurrence - realization of service, effect of providing service. 3. "Becoming" - after-effects, creation of particular value. Services at the stage of readiness to their provision, as noted by M. Daszkowska, have a task of maintaining means of labor efficient and creating the conditions for development of skills employed in the process of production. What is more, they should enable regeneration of labor. In the exchange stage however, the function of services amounts to the freedom of choice. A consumer may abandon a service or exchange it into substitute good or other service. At the consumption stage, final services satisfy new needs and affect the structure of consuming.

The basis of economic calculation in services is relative rationality based on a socially-conditioned system of values which is manifested in multidimensional structure of information space. However, one may detail criteria for an optimal choice of an operation variant in services. The following items are worth noting (Daszkowska, 1982): maximizing the quantity (value) of production of services in certain conditions that limit the volume of expenditure (investments, labor, materials) and service structure by type; minimizing expenditure while performing certain tasks 
in the scope of service production and spatial location of demand for those services; maximizing the profit in conditions of limited service structure by type; various combinations of the above criteria.

It is worth stressing that the economic outcome of the course of action (in various service fields) may be reflected in (Skapska, 2010): reduction of service provision costs due to innovation i.e. supporting service with selfservice, technologization; saving rare resources necessary for the process of provision. Rationality of operation in the field of service research should be analyzed not only in terms of means, but also in the terms of relations.

\section{Classical and cyberspace relation in service provision process}

Provider-consumer relations may be simple and unambiguous or complicated and emotional. An important component of this interaction is (it seems to be) personalization of services, which, according to D. Ball, S. Pedro, means an each "deliverable" or adjusting service to individual requirements of a client. To a large degree it requires meeting three conditions (Ball, Pedro, 2006): A service provider wishes and is able to adjust the offer to an individual client; A client's needs differ from other clients; Communication between a client and a service provider leading to establishing personalization - what is required by the client and what can be uniquely done for this client.

The following instruments (Bairi, Manahar, 2011) influence, and contribute to, the improvement of service management skills: exchange of information - as communication is the simplest business principle; the basis - creating positive impression; vision - viewing rendering services as a chain of events; message resulting in understanding; motivation to contact a client; teamwork.

A certain convenience connected with movement of information is a Content Management System (CMS) using data transmission via the network. It regards business files such as memoranda, photos, graphics, spreadsheets. After being passed they may be processed even further. Another system improving the access to information is Customer Relationship Management (CRM), i.e. building customer relations by means of Electronic Data Interchange (EDI). Moreover, according to D.H. Gleason and L. Friedman (Gleason, Friedman, 2005), Open Systems Interconnection (OSI) may be used as a basic educational tool which should help people to understand information and communication technology (ICT) that is necessary to protect public interest from the cyberspace. An example of IT usage in tourist services is an organization dealing with managing the destinations for tourist traffic, namely, Destination Management Organizations (DMOs). In healthcare systems a new branch of activity is e-health which includes numerous advanced IT technologies that support its functioning. The CRM techniques are especially important in distribution and service provision. Specialized systems operating of Supply Chain Management (SCM) have another vital and universal meaning to many service categories. They concern, among others, B2B type e-markets, invoicing of supplies and payments.

H.T. Keh and J. Pang, while comparing means of providing services with respect to expenditure and time savings during the access to and use of service and selection of place and the time of provision, have concluded that separation of production and consumption is a more beneficial form. However, this type of provision is not devoid of risk concerning an important issue of information asymmetry (Keh, Pang, 2010). The problem consists in discrepancy between what the selling enterprise knows, and what it should know in order to fully satisfy their clients' needs (Pagliacci, Kędzior, 2006).

Cooperation between actors in this market play is managed in a way that takes into consideration various network service groups. Therefore, one considers entities or processes taking part in the interaction with the service and distinguishes (according to Plummer) the following service types (Winiarski, 2003): client-oriented, 
business-oriented, devices and systems. Subsequently their functioning is based on a tripartite model of interaction consisting of: 1. Ordering party i.e. the party passing the demand for finding and using a particular type of service. 2. Broker - a middleman between a service provider and an ordering party in case when they possess proper access to information about service providers published in specialized, network-service dedicated registers and 3. Service provider who is responsible for the implementation of network service and providing the broker with the required information and, in many cases, also registering the service in a metadata repository.

The enterprises characterized by great dependence on IT services, for example in retail, insurances, telecommunication and banking, face the challenge of integrating IT systems which is extremely troublesome as the process requires continuous alterations in service operations in order to maintain high quality of customer service. Stoppage or malfunctions of the system may have catastrophic consequences for profitability and relations with clients. The key aspect of the service provision process is trusting one's IT service provider (Montaya, Massey, 2010).

\section{Conclusions}

To sum up one may state that, as opposed to the production process, the process of rendering services is long and it has a complicated course of intangible nature. Intellectual capital of the personnel providing service plays a significant role in the process. The key potential is ability to transform information into useful knowledge. An indispensable component of an economic process is "service personalization". However, the space, in which the contact between a service provider and a service receiver takes place, shrinks inevitably. Its major agenda item is a digital message using modern technologies that has transformed a consumer into e-consumer and services into e-services. Therefore, the very process of providing services may be described as a sequence of multidimensional functional transformations of operators.

$f_{i}: R^{n} \rightarrow R^{m}$, where $i, n, m$ are elements of the $N_{+}$set. $f_{i}$ is the $i$-th function of economic decisions made by the entity. $R^{n}$ - is $n$-dimensional space of information technology originating from the production sector. $R^{m}-$ is $\mathrm{m}$-dimensional space of economic effects treated as sub-space of the global economic market (Juzwiszyn, 2003). Thanks to this kind of approach towards analysis of multidimensional information structures in an economic service process, the process itself is nothing more than an algebraic family of multidimensional linear operators (Juzwiszyn, 2008). On the global market of economic connections rational administration is nothing more than multidimensional over-space of all information structures existing in the service process.

\section{References}

Bairi, J., Manahar, B.M. (2011). Critical success factors in gaining user customer satisfaction in outsourced IT services. Journal of Enterprise Information Management, 24 (6), 475-493.

Ball, D., Pedro, S. (2006). Service personalization and loyalty. Journal of Services Marketing, 20 (6), 391-403.

Daszkowska, M. (1982). Ekonomika i organizacja usług. Warszawa: PWN.

Gleason, D.H., Friedman, L. (2005). Proposal for an accessible conception of cyberspace. Journal of Information, Communication and Ethics in Society, 3 (1), 15-23.

Jakimowicz, A., Juzwiszyn, J. (2012). Vortex Stabilization of Market Equilibrium in Theory and in Practice of Economics. Acta Physica Polonica, A, 121 | 2B | B-54-B-60.

Juzwiszyn, J. (2003). Concerning the Revolution of Financial Spheres. Applications of Physics in Financial Analyses 4. V. n. 27C. Warszawa: Warsaw University of Technology, A97. 
Juzwiszyn, J. (2008). DNA rynku. Zeszyty Naukowe Politechniki Białostockiej Ekonomia i Zarządzanie, 115-127.

Keh, H.T., Pang, J. (2010). Customer Reactions to Service Separation. Journal of Marketing, March, 56-57.

Leibenstein, H. (1995). The Supply of Entrepreneurship. Leading Issues in Economic Development. New York: Oxford University Press.

Montaya, M.M., Massey, A.P., Khatri, V. (2010). Connecting IT Services Operations to Services Marketing Practices. Journal of Management Information Systems, 26 (4), 65-85.

Mytlewski, A. (2007). Monitoring ekonomiczny przedsiębiorstw. Gdańsk: University of Gdańsk.

Pagliacci, G.R., Kędzior, Z. (2006). Informacyjna rola sprzedawców w przedsiębiorstwie. Marketing i Rynek, 11, 2-6.

Payne, A. (1993). The Essence of Service Marketing. London: Prentice Hall.

Rogoziński, K. (2014). Service Design - czworako ujęty. Prace Naukowe Uniwersytetu Ekonomicznego we Wrocławiu, 354.

Rogoziński, K. (2003). Cywilizacja usługowa - samorealizujące się niespełnienie. Poznań: Akademia Ekonomiczna w Poznaniu.

Rogoziński, K. (2010). Zarys pozytywnej teorii usług. Zeszyty Naukowe Uniwersytetu Ekonomicznego w Poznaniu, 145, 241-269.

Shannon, C.E. (1948). A Mathematical Theory of Communication. The Bell System Technical Journal, 27.

Skąpska, E. (2010). Ekonomiczny wymiar wieloaspektowego podejścia do przedsiębiorczości usługowej. Zeszyty Naukowe Uniwersytetu Ekonomicznego w Poznaniu, 145, 213-225.

Skąpska, E. (2012). Usługa informacyjna jako rezultat współpracy międzyorganizacyjnej. Zeszyty Naukowe Uniwersytetu Ekonomicznego w Poznaniu, 229, 234-248.

Skąpska, E. (2014). Oblicza racjonalności w ekonomice usług. Studia Ekonomiczne, 180, 213-225.

Winiarski, J. (2003). Sieci komputerowe w biznesie. Informatyka Ekonomiczna, 11, 42-44.

Cite this article aS: Skąpska, E. (2016). Analysis of multidimensional information structures in economic service process - nonlinear approach. European Journal of Service Management, 17 (1), 51-56. DOI: 10.18276/ejsm.2016.17/1-07. 